\title{
AN EVALUATION OF STUDENTS SKILLS AND EXPACTATIONS RELATED WITH THE JOB ASPIRATIONS
}

\author{
Muntean Andreea ${ }^{1}$ \\ Dobra Iulian Bogdan ${ }^{2}$
}

\begin{abstract}
The overall objective of the research is to evaluate the students' skills and aspirations, in order to highlight the professional features and opportunities they had acquired after graduation. Primary data were collected by questionnaire.

The results can be used to describe the profile of the students from Economics with regard to the identification of skills that a company's employee or manager should have.

The questionnaire tackled three aspects: a general theoretical one, the other focused on the transition from school to active life, and the last aimed at the students' skills and expectations.

It was intended to outline a student profile by identifying the expectations and abilities of the persons surveyed, and also to identify the respondents' opinions on the attitude regarding the students' level of practical knowledge and on the importance of their theoretical professional training, their practical training and their professional experience for the future job.
\end{abstract}

Key words: students' skills, students' profile, job opportunities, economic education

JEL Code: $A 2$

\section{Introduction}

In the dynamic structure of the economics university education, meant for an effort of thinking, knowledge and communication, specialized practice is one of the most important stages. It tends to mobilize intellectual, emotional and practical faculties (Johannisson, B., 1998), being unable to imagine the process of active transmission and reception of knowledge in the absence of an alert guide. Thus, the specialized practice is part of the succession of the university program, among its main constituents.

As the meaning of practical activities is the responsibility of future specialists in business management (Gartner, W. 1993), it is important to understand the significance of the relationship, with so many implications, between the university teacher, the student and the specialist (as practice supervisor), which consolidates the principles of a modern, active education, presided over by the concepts of a scientific vision on economic reality (Champley D., Cropley, AJ 2000).

\footnotetext{
1 “1 Decembrie 1918” University of Alba Iulia, Faculty of Economics, andreea.muntean@uab.ro

2 “1 Decembrie 1918” University of Alba Iulia, Faculty of Economics, dobra.iulian@uab.ro
} 
The need to train future specialists in Business Administration, Marketing, Economy of Trade, Tourism and Services, Accounting and Management Informatics and Finance and Banks, according to higher demands and standards, increases the responsibility of the stakeholders.

The need for practical action, along with good theoretical training specific to the field, is justified by the fact that the student must acquire a series of qualifications, abilities and practical skills in order to be able to perform efficiently, to support the decision or to decide on different issues of business management.

The experience thus gained by the future professionals cannot be supplemented by anything else, not even by the best and most complex theory.

\section{Research methodology}

The aim of the research is to identify the students' expectations and skills regarding the theoretical and practical preparation following their undergraduate studies.

The research objectives were formulated as follows:

1. Determining the students' opinion on professional skills and abilities

2. Identifying the current approaches to the transition from school to active life

3. Assessing the students' skills.

Data were collected using a sample of 200 students in Economics. The questionnaire included 15 closed, open and mixed questions and was structured on four parts: I. Information on the respondent - student, II. Basic theoretical approaches to the professional skills, III. Approaches addressing the transition from school to active life and IV. Assessment of students' skills.

The application of the questionnaire, as a flexible research tool, allowed data to be collected by means of closed and open questions. They were structured according to well-defined principles, so that they raised the interest of the respondents and trained them to respond as honest and as clear as possible to the questions asked.

In the formulation of questions, nominal (questions $2 \mathrm{a}, 2 \mathrm{c}, 3 \mathrm{a}, 3 \mathrm{~b}, 3 \mathrm{c}, 4 \mathrm{e}, 4 \mathrm{f}$ ), ordinal (question $4 \mathrm{~d}$ ) and interval (questions $4 \mathrm{a}, 2 \mathrm{~b}$ ) scales were used to measure the research variables. Open questions were used to evaluate the other variables.

The questionnaire answer choices were encoded, each choice having a numerical value. These values were afterwards entered into a database so as to allow further analysis process.

The structure of the students sample used was as follows: $30 \%$ of the students surveyed were from the Economy of Trade, Tourism and Services, 28.5\% from Business Administration, 20\% from Marketing, $10 \%$ from Finance and Banks and 9.5\% from the Accounting and Management Informatics specialization.

Most of the students surveyed were enrolled in the first year of study (85\% of them).

Regarding the study scheme, the share of students under subsidy in the total sample (46\%) is roughly equal to that of the students in the fee-based scheme (52.5\%). 
In the structure of the sample, most of the investigated, namely 156 students out of the total of 200, didn't benefit from scholarship.

\section{Results}

The data collected were processed and analysed using the data statistical analysis software, SPSS, version 17.0. The method used was the univariate analysis with the help of frequency distribution.

The second part of the questionnaire, following the data collected about the respondents' profile, aimed at the students' opinions on professional skills and abilities. This was conducted with the help of a closed question with four choices of answer. More than half of the investigated students (56\% of the total sample) consider that professional skills and abilities have both an innate dimension and a training component, and $31.5 \%$ of the respondents believe that these skills are rather the result of work experience. Very few students, think that they are innate.

Further on, using the Likert's scale, the students included in the sample were asked to express their agreement/disagreement about the following statement: "Professional skills and abilities are complex structures, consisting of general and specific competences". The results showed that most respondents expressed their "Agreement" (71.5\%) and "Total Agreement" (20.5\%) in relation to the above statement. No "Disagreement" or "Total Disagreement" response was recorded.

The next question of the questionnaire asked respondents to appreciate which of the 8 key competences stipulated by the European Union are essential for a future job. These competences are: linguistic competence (in native language), linguistic competence (in foreign language), mathematical competence, learning competence, civic competences, interpersonal, intercultural and social competences, entrepreneurial competence, cultural expression.

A number of 185 respondents appreciate that these skills are essential, the most often mentioned (in the order of frequency of occurrence): the entrepreneurial competence, the scientific and technological competence, learning competence, civic, interpersonal skills.

In the third part of the questionnaire, students' approaches to the transition from school to active life were assessed using three questions.

Thus, according to $47.5 \%$ of respondents, the Bachelor's degree studies provide a balanced rate between theoretical and practical training, while $39 \%$ of them consider that Bachelor's degree studies provide them sufficient theoretical training, unlike the insufficient practical training. A very small percentage (5\% of the respondents) appreciate that their undergraduate studies offer sufficient practical training in imbalance with the insufficient theoretical training.

As far as the surveyed students' opinion about the share of specialized practice trainee-ships in their total study program, $26 \%$ of them believe that this percentage should be $50 \%$, and the same 
number think it should be in the range $25 \%-50 \%$. For nearly $20 \%$ of respondents, the share of total practice should be dominant - between $50 \%$ and $75 \%$.

The fourth section of the questionnaire was made up of questions designed to evaluate students' skills. With the help of six scale ranges, with 5 levels (from 5-Very High to 1-Very Low), it was assessed the extent to which, in their opinion, students can achieve certain work objectives based on the acquired knowledge to date, namely: Recognizing the decision-making skills, Familiarizing with risky and uncertainty situations, Knowing the management techniques, Integrating the input from different business functions, Developing a team work plan, Strategic orientation training. The results are shown in Table 1:

Table 1. Assessment of students' skills

\begin{tabular}{|c|c|c|c|c|c|}
\hline \multirow[t]{2}{*}{ Objective: } & \multicolumn{5}{|c|}{ Relative frequencies $(\%)$} \\
\hline & $\begin{array}{lr}5-\text { To } \\
\text { a } & \text { great } \\
\text { extent } & \end{array}$ & 4 & 3 & 2 & \begin{tabular}{lrr} 
& \multicolumn{1}{r}{-} \\
To a & very \\
small extent
\end{tabular} \\
\hline $\begin{array}{c}\text { Recognition of } \\
\text { decision-making skills }\end{array}$ & 21 & 42 &, $5 \%$ & $\%$ & $1,5 \%$ \\
\hline $\begin{array}{l}\text { Familiarization } \\
\text { with risky and } \\
\text { uncertainty situations }\end{array}$ & $12 \%$ & 31 &, $5 \%$ & $0 \%$ & $5 \%$ \\
\hline $\begin{array}{c}\text { Knowing the } \\
\text { management techniques }\end{array}$ & $13 \%$ & 33 & 31 & $4 \%$ & $1,5 \%$ \\
\hline $\begin{array}{l}\text { Integrating the } \\
\text { input from different } \\
\text { business functions }\end{array}$ & $10 \%$ & 29 &, $5 \%$ & $4 \%$ & $3,5 \%$ \\
\hline $\begin{array}{l}\text { Developing a } \\
\text { team work plan }\end{array}$ & $32 \%$ & 37,7 & 16 &, $5 \%$ & $1,5 \%$ \\
\hline $\begin{array}{c}\text { Strategic } \\
\text { orientation training }\end{array}$ & $17,5 \%$ & 35 &, $5 \%$ &, $5 \%$ & $3 \%$ \\
\hline
\end{tabular}

Source: author's contribution

By interpreting the data from the table above, it can be appreciated that most of the students surveyed, in their opinion, can achieve work objectives such as: decision-making, developing a team plan, developing strategic guidance, applying management techniques. They feel least prepared for familiarization with risky and uncertainty situations and with the integration of inputs from different business functions.

Self-evaluation of strengths and weaknesses as future employees of the surveyed students was pursued by means of two open questions. 
Among their strengths there have been mentioned individual features such as: competitiveness, entrepreneurship, good theoretical training, the ability to apply the theory in practice, good communication with partners, good generalization capacity, knowledge of a foreign language (in most cases english), willingness to learn new things, sociability, determination, practical spirit, interpersonal skills, reliability, computer skills, concern for further studies and specialization, involvement, initiative.

Also, the surveyed students estimate that their weaknesses as future employees would be: poorly practically trained, lack of interdepartmental communication (individualism), lack of theoretical correlation in practice, negative attitude, lack of knowledge of legislation, lack of communication, superficiality, poor theoretical knowledge, need orientation on every step, synthesis capacity, insufficient foreign language skills, lack of proactivity, lack of realism, initiative, lack of teamwork ability, disinterest.

In the questioned students' opinion, the students major in economics form their professional skills primarily during their practical training sessions, then from tutors, from courses and seminars, from their own experience, from media, from the Internet and, lastly, from colleagues and friends or from reading.

Regarding the distribution of students according to their expectations for finding a job corresponding to their training, during the first 6 months after graduation: for $36 \%$ of them, expectations are "High", while for nearly $20 \%$ of the respondents they are "Low" and "Very Low". About $30 \%$ of them have no expectation of finding a post-graduate job.

\section{Conclusions}

Thus, in the curricula developed for Business Administration, Marketing, Economy of Trade, Tourism and Services, Accounting and Management Informatics, and Banks and Finance, the practical training component performs a scientific inquiry, an act of initiation, practice and last but not least, a direct contact with reality.

Taking contact with organizations' different practical situations and perceiving their real complexity, self-evaluation and the permanent completion of the information, as well as the abilities and skills system, turn the student into the future specialist in business management.

Business Administration, Marketing, Economy of Trade, Tourism and Services, Accounting and Management Informatics and Finance and Banks are addressed to the graduates of the preuniversity education and aims to scientifically and practically prepare business management specialists.

The graduates of this program will be able to collect, process and analyze economic and financial information, to develop a business plan, to formulate and implement marketing strategies and policies. 
In terms of university practice, undergraduate studies provide students with sufficient theoretical training, in imbalance with the insufficient practical training, and the importance of practical vocational training for specialized preparation in relation to other activities specific to the academic program is extremely high (between $25 \%$ and $50 \%$ ). The research has helped identify students' skills and expectations on the characteristics and career opportunities accumulated after graduation.

\section{References:}

1. Becker W. E., Teaching Economics to Undergraduates, Journal of Economic Literature, Vol. 35, No. 3, pp. 1347-1373, 1997

2. Champley David, Teaching Entrepreneurship to Students, http://ezinearticles.com/?Teaching-Entrepreneurship-to-tudents\&id=4097281

3. Cropley, A.J., Defining and measuring creativity: are creativity tests worth using?, Roeper Review, Vol. 23, 2000

4. Gartner, W.B. Words lead to deeds: toward an organizational emergence vocabulary, Journal of Business Venturing, Vol. 8, No. 3, pp.231-240, 1993

5. Green, F. and McIntosh, S., Is there a genuine underutilisation of skills amongst the over-qualified?, SKOPE Research Paper No. 30, ESRC Centre on Skills, Knowledge and Organisational Performance, Oxford and Warwick Universities, 2002

6. Johannisson, B., Landström, H. and Rosenberg, J., University training for entrepreneurship - an action frame of reference, European Journal of Engineering Education, Vol. 23, 1998

7. Mason G., Williams G., Cranmer S., Employability skills initiatives in higher education: what effects do they have on graduate labour market outcomes?, Education Economics, 17:1, 1-30, DOI: 10.1080/09645290802028315, 2009

8. Smith, J., McKnight, A., Naylor, R., Graduate employability: Policy and performance in Higher Education in the UK, Economic Journal, 110: F382-411, 2000

9. Teichler, U., Graduate employment and work in selected European countries. European Journal of Education, 35(2): 141-55, 2000 